\title{
An Analysis of Kuwait Economy 1995-2015
}

\author{
Munir Hassan ${ }^{1}$, Anwar Al Shriaan ${ }^{1} \&$ Abdullah k Al-Mutairi ${ }^{2}$ \\ ${ }^{1}$ Kuwait University \\ ${ }^{2}$ Gulf University of Science \& Technology (GUST)
}

Received: September 26, 2017

doi:10.5539/ass.v13n12p24

\author{
Accepted: October 11, 2017 \\ Online Published: November 28, 2017 \\ URL: https://doi.org/10.5539/ass.v13n12p24
}

\begin{abstract}
The main objective of the paper is to examine the performance of the Kuwait economy internally and externally for the period, 1995-2015. The paper is presented in five sections. In the first section, a short profile of Kuwait is given in terms of its historical and demographic characteristics. A concise Review of Literature is given in Section 2. The third section is devoted to the macro and micro variables performance for the Kuwait economy. International trade is the focus for the fourth section with emphasis on export and import growth and index of openness. In trying to assess the external trade of the Kuwait economy, an attempt is made to present and analyze t Revealed Comparative Advantage for selected years and selected commodities. The choice of the years and commodities is dictated by availability of data.
\end{abstract}

\section{Profile of Kuwait}

In this, section a brief profile of Kuwait is given in terms of its economic, political and demographic aspects.

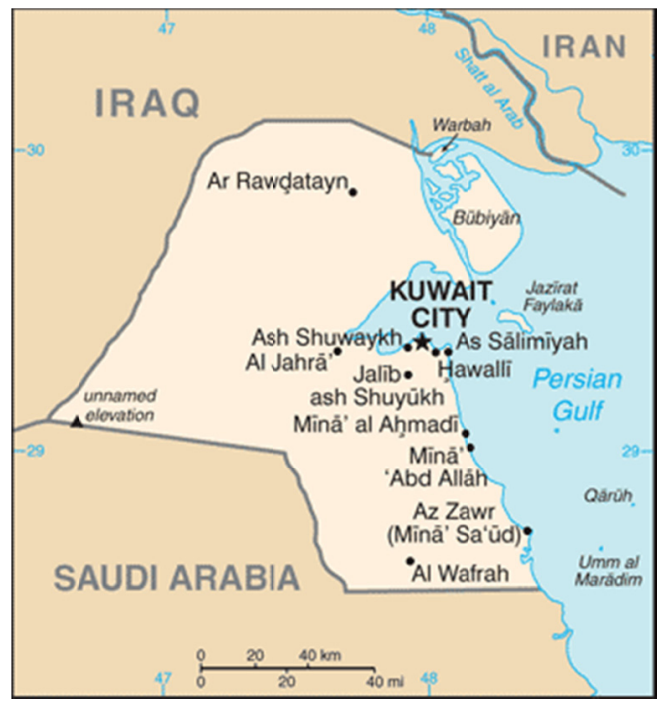

Figure 1.

Kuwait is located in the Middle East, bordering the Persian Gulf, between Iraq and Saudi Arabia. It is strategically located at the head of the Persian Gulf. It has a total area of 17,818 sq.km and ranks 158 in the world. It is dry desert with intensely hot summers and short cool winters.

Kuwait economy is geographically small but wealthy. It is a relatively open economy with crude oil reserves of about 102 billion barrels, which is more than $6 \%$ of world reserves. It is ranked 61 in terms of GDP (Purchasing Power Parity) with an estimate of $\$ 165.8$ billion in 2013 . The real GDP growth rate is $2.3 \%$ and GDP per capita is $\$ 42,100$ and ranks 24th in the world. It is interesting to note that it ranks second in the world with respect to Gross National Savings. By saving annually $10 \%$ of government revenue in the Fund for Future Generations, the government has cushioned itself against the impact of lower oil prices. Because of uncertain political situation and poor business climate, the Kuwait economy was not able to progress as fast as it could. It was difficult to attract more investment or boost the private sector participation in the economy. (World Fact Book 2017)

Household Consumption and Government consumption are $23.9 \%$ and $16.4 \%$ of GDP respectively. Investment in Fixed capital is $16.2 \%$ whereas there is no investment in inventories. Kuwait has a balance of trade Surplus as Exports of Goods and Services are greater than imports of Goods and Services. Exports are \$112 billion and Imports are $\$ 24.42$ billion. The export commodities are oil and refined products and fertilizers and the export partners are South Korea (16.1\%), India (15.7\%); USA (11.7\%); China (9.2\%); and Singapore (4.2\%). Import Commodities are food, 
construction materials, vehicles and parts and clothing and the import partners are USA (11.8\%); China (9.2\%); Saudi Arabia (8.6\%); Japan (8.2\%); South Korea (6.9\%), Germany (5.1\%); India ( $4.6 \%)$ and UAE (4.4\%). Industry and Services contribute $50.6 \%$ and $49.1 \%$ respectively to GDP whereas Agriculture is only .3\%. Labor Force is 2.38 million and about $60 \%$ are non-Kuwaiti. It ranks $27^{\text {th }}$ in the world with respect to unemployment rate which is $3.4 \%$. It ranks first with respect to Budget Surplus (29.2 \%) of GDP. Revenues are \$114.1 billion and Expenditures are \$61.81 billion.

In Kuwait, the government spending is driving sector growth, diversified segments are seeing successes, environmental regulations are being implemented and the petrochemical segment is getting a boost. Kuwait provides a stable economic environment and one of the largest markets in the gulf. In spite of the softening of oil prices in the wake of the global economic crisis, the petrochemicals industry in Kuwait continued to prosper. Profits were high in 2009.

The Kuwait Government through its petrochemicals arms, Petrochemicals Industries Company (PIC) has entered into successful joint ventures with foreign partners that have brought technology, marketing and operational expertise into the country. The government has also promoted privatization of the sector through the two investment vehicles Boubyan Petrochemicals and Qurain Petrochemicals Industries Company (QPIC).The three players, PIC, foreign partners and private sector form a dynamic combination that could lead to increased competitiveness and profitability and joint ventures that are more successful in the future.

Kuwait has several advantages as manufacturing and trading base. It is conveniently located at the mouth of the gulf which gives it easy and quick access to Iraq, Iran fellow GCC nations and locations farther in field-nations in Central Asia and the Indian subcontinent. In 2009/10, the major advantage was its very strong fiscal position with a budget surplus of some $\$ 17 \mathrm{bn}$. The Government has emphasized on environmental regulation and as a result, many industrial firms are working hard to meet health and safety standards.

\section{Review of Literature}

Most of the information reviewed in this section is the reports by different organizations. The academic literature on Kuwait economy is scanty and none was available for the period under study. In this article, "Bypassed by Dubai, Kuwait fails to keep up with its neighbours", it is stated that Kuwaitis often compare their country with the other states of the Gulf. Kuwait has the highest GDP per person in the region and the fourth highest in the world. This is due to their large oil reserves and small population. However, in recent years it has fallen behind countries like Qatar, United Arab Emirates (UAE). Kuwait has one distinguishing characteristic, and that is: it is the closest to a democracy in the Gulf.

According to the report in the Economist, political tensions will remain high and another set of elections may take place in 2017-2018. The prediction is that the fiscal position will remain in deficit in 2017-18-21, given the dependence on oil revenue. The optimistic note in the report is that real GDP will rise from .6\% in 2017, with OPEC-agreed oil output cuts weighing on growth, to an average of 3.2\% in 2018-21 as sentiment gradually improves.

In The IMF Report, it is stated that:

"Growth was resilient in 2015 as rising output in the non-oil sector more than offset a contraction in the oil sector. Financial buffers remain large, but fiscal flow positions have sharply deteriorated, prompting fuel subsidy reform. Major infrastructure projects should continue to support growth in the near to medium term. Key challenges include the need to anchor fiscal sustainability, improve natural resource wealth management and economic diversification. Poverty is not an issue for Kuwaiti citizens."

The Kuwait Staff Concluding Statement of the 2016 Article IV Mission states that "Kuwait's fiscal and external accounts have been adversely affected by the lower oil prices, and financing needs have emerged. Resilient nonoil activity and strong oversight by the Central Bank of Kuwait have kept the financial sector sound. The key challenge for policymakers is to implement the government's comprehensive six-pillar reform plan, which aims at promoting fiscal consolidation and boosting private sector growth, diversification, and job creation for nationals. Notwithstanding large buffers that provide policy space to smooth the necessary adjustment, policymakers have initiated important fiscal reforms. These should be sustained to gradually raise fiscal savings, focusing on further rationalizing energy subsidies, containing the wage bill and increasing nonoil revenue, which will create space for higher growth-enhancing capital outlays. Better aligning labor market incentives, promoting higher productivity through privatization and partnerships with the private sector, and further efforts to improve the business climate are key to encourage diversification, private sector development and employment opportunities for nationals. The Staff commented on the recent Macro-Financial Developments stating that:

- Economic Activity in the non-oil sector has continued to expand at a lower space reflecting the impact of lower prices.

- The financial sector has remained sound and credit conditions are favorable, however the fiscal and external accounts have deteriorated markedly.

- The government also has started borrowing as financial needs have been met so far by drawing down financial buffers The Central Bank of Kuwait has highlighted some economic facts for Kuwait in its 2015 economic report. The report shows that Gross Domestic Product (GDP) amounted to 40 billion dinars ( $\$ 132$ billion) which depicts a growth of $1.8 \%$ 
compared to 2014. However, the report point out that Kuwait faces challenges of declining oil prices, the need to address the situation of various sectors and the importance of stimulating the various core activities in the oil and non-oil sectors.

Considering the scarcity of literature on this particular topic for this period, it was thought imperative to do a detailed analysis of Kuwait economy.

\section{Performance of Macro Variables in Kuwait Economy}

In this section, an attempt is made to examine the growth and performance of certain selected macro variables for the Kuwait economy. The variables selected are Gross Domestic Product, Population, GDP, Unemployment, inflation, FDI inflow and Public Debt.

Kuwait economy has by an estimated $3 \%$ in 2016 supported by higher oil production and implementation of the Development plan.

The Table below gives some of the forecasts by World Bank.

Table 1. Kuwait / Macro outlook indicators (annual percent change unless indicated otherwise)

\begin{tabular}{|c|c|c|c|c|c|c|}
\hline & 2014 & 2015 & $2016 \mathrm{f}$ & $2017 \mathrm{f}$ & $2018 \mathrm{f}$ & $2019 \mathrm{f}$ \\
\hline Real GDP growth, at constant market prices & 0.5 & 1.8 & 3.0 & 2.5 & 2.6 & 3.2 \\
\hline Private Consumption & 4.9 & 2.4 & 4.0 & 4.0 & 2.9 & 2.9 \\
\hline Government Consumption & -0.8 & -0.5 & -14.5 & 4.8 & 2.9 & 1.9 \\
\hline Gross Fixed Capital Investment & 4.6 & 13.0 & 10.4 & 6.3 & 4.0 & 5.0 \\
\hline Exports, Goods and Services & 1.4 & 1.0 & 4.8 & 1.0 & 2.7 & 3.4 \\
\hline Imports, Goods and Services & 8.0 & 5.1 & 3.5 & 4.3 & 4.1 & 4.1 \\
\hline Real GDP growth, at constant factor prices & 1.0 & -0.3 & 3.0 & 2.5 & 2.6 & 3.0 \\
\hline Agriculture & 7.5 & 4.2 & 2.0 & 2.0 & 2.0 & 2.0 \\
\hline Industry & -0.5 & -1.7 & 2.4 & 1.8 & 1.7 & 2.4 \\
\hline Services & 3.3 & 1.9 & 3.8 & 3.4 & 4.0 & 3.9 \\
\hline Inflation (Consumer Price Index) & 2.9 & 3.3 & 3.2 & 3.5 & 3.0 & 3.0 \\
\hline Current Account Balance (\% of GDP) & 33.2 & 7.5 & 1.9 & 5.0 & 5.5 & 6.1 \\
\hline Financial and Capital Account (\% of GDP) & -36.8 & -11.2 & -5.7 & -8.6 & -9.1 & -9.8 \\
\hline Net Foreign Direct Investment (\% of GDP) & -8.4 & -8.4 & -5.0 & -3.0 & -2.0 & -2.0 \\
\hline Fiscal Balance (\% of GDP) ${ }^{a}$ & 18.0 & -0.4 & 0.5 & 4.6 & 4.8 & 4.7 \\
\hline Ex. inv. Income and after transfers to SWF & 4.6 & -17.6 & -17.1 & -11.9 & -10.6 & -11.1 \\
\hline Debt (\% of GDP) & 16.3 & 7.2 & 11.8 & 17.2 & 20.0 & 20.0 \\
\hline Primary Balance (\% of GDP) & 18.1 & 0.0 & 0.6 & 4.7 & 5.1 & 5.0 \\
\hline
\end{tabular}

Sources: World Bank, Macroeconomics, and Fiscal management Global practice. Note: $\mathrm{f}=$ forecast

${ }^{a}$ Fiscal balance data is reported on a general government $\mathrm{t}$ basis i.e. before transfers to the sovereign wealth fund and including investment income

The above table gives the forecasts for selected macro variables in the Kuwait economy. The GDP growth is expected to increase consistently over this period for Real GDP growth at constant market prices and at constant factor prices. Private consumption (maximum value 4.9 in 2014); Government consumption ( maximum value 4.8 in 2017)); Gross Fixed capital investment ( maximum value 13.0 in 2015);Exports, Goods and services ( maximum value 4.8 in 2016); Imports, Goods and services ( maximum value $8.0 \mathrm{n}$ 2014); Industry growth rate ( maximum 2.4 in 2016 and 2019 ); Services ( maximum value in 4.0 in 2018) ; Inflation ( maximum value in 3.5 in 2017); Current Account Balance ( maximum 33.2 in 2014; Fiscal Balance ( maximum value in 2014) ; Debt ( maximum value in 2018 and 2019) and Primary Balance ( maximum value in 18.1 in 2014). For all these variables, the other years exhibited fluctuations. Financial and Capital Account and Net Foreign Direct investment manifested negative values for the annual percentage changes.

Detailed graphs are given for the selected economic variables for the Kuwait economy for the periods 2002-2008 and 2009-2015.The actual data is attached is given in the appendix.



Figure 1. Annual \% Change in Kuwait's Population, 2002-2015

From the above Figure 1, it is observed that whereas the population change has been increasing from 2002- 2008 there 
is a decline in the period from 2009- 2015.



Figure 2. Population Density, Persons per Square Mile, Kuwait, 2002-2015

The density as observed from the above Figure 2 is seen to consistently increase for both periods 2002-2008 and 2009-2015 with density being much higher in the latter period.

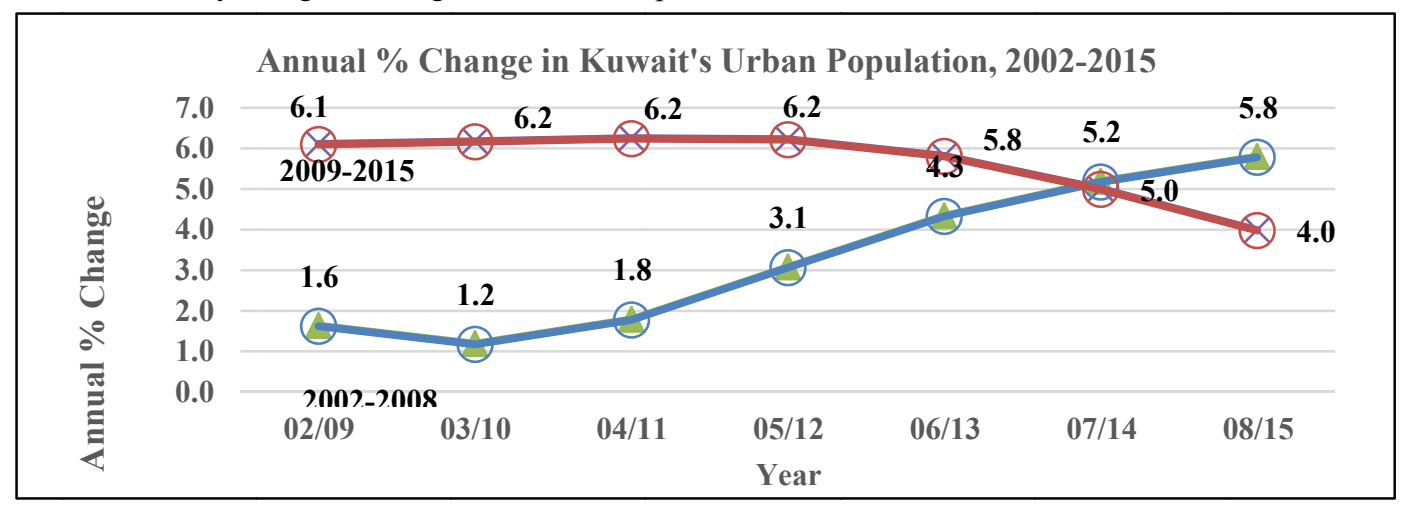

Figure 3. Annual \% Change in Kuwait's Urban Population, 2002-2015

The annual \% change in Kuwait's Urban Population has depicted increase in the period 2003-2008 and decline from 2009- 2015 as observed in Figure 3.

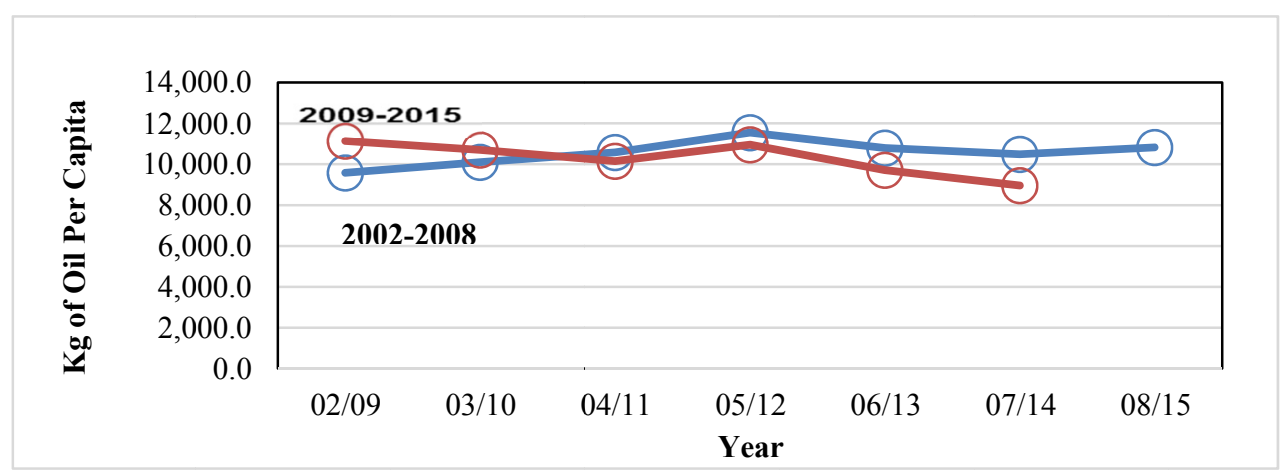

Figure 4. Energy Use, Kg of Oil Per Capita, Kuwait, 2002-2015

As the above Figure 4 reveals the energy, use has followed the same pattern in both the periods 2002-2008 and 2009-2015.

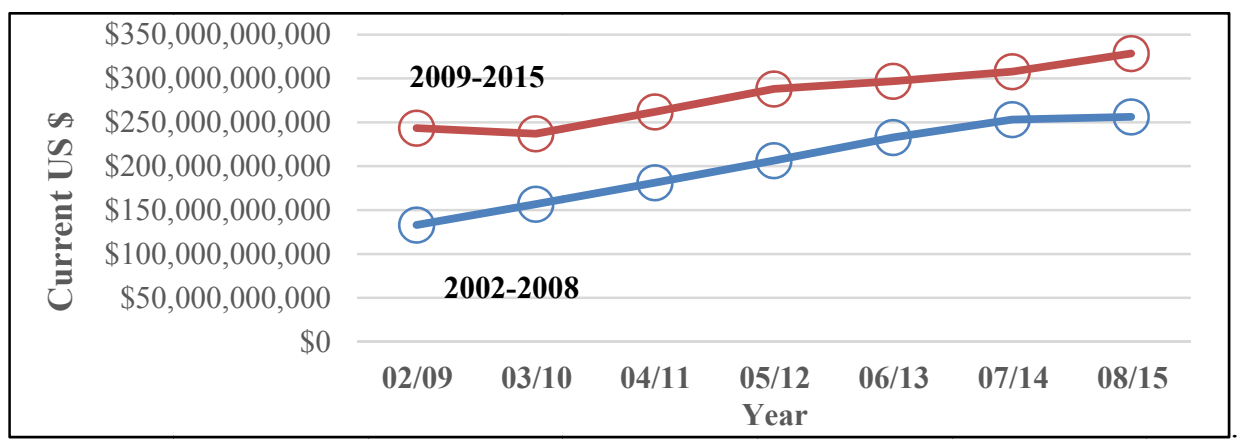

Figure 5. GNI, Purchasing Power Parity, Kuwait, 2002-2015 
GNI, Purchasing Parity as seen from the Figure 5 above depicts consistent increases for both periods 2002-2008 and 2009-2015.

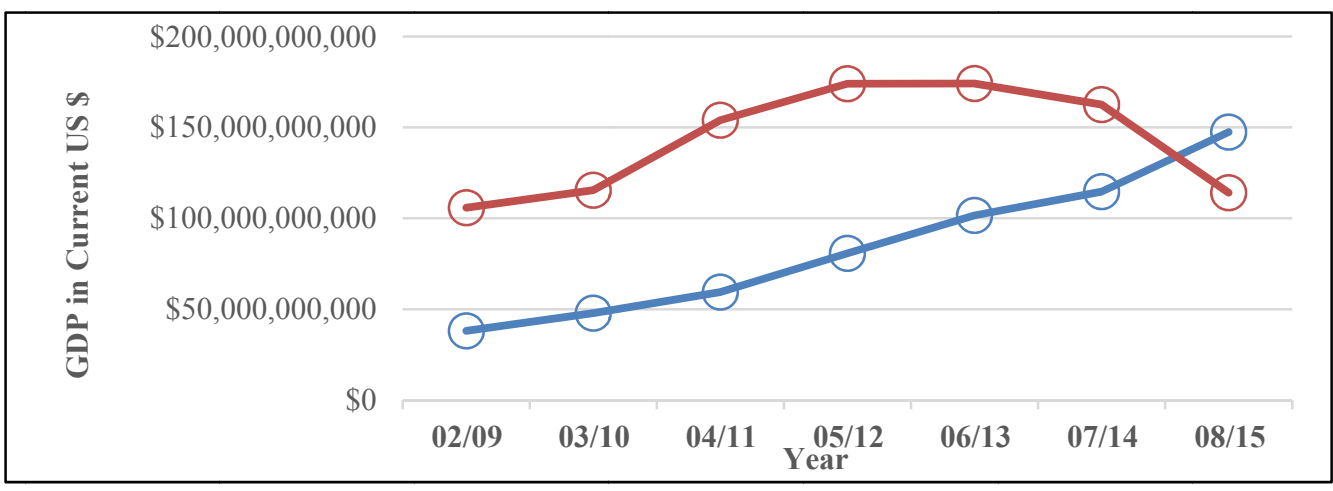

Figure 6. Gross Domestic Product, Kuwait, 2002-2015



Figure 7. Annual \% Change in GDP, Kuwait, 2002-2015

Figure 6 reveals that GDP has consistently increased over the period 2002-2008 but has taken a dip after 2013.The low oil prices seem to have an impact for this period.

As can be seen from the above Figure 7 the Annual \% change is GDP has gone through violent fluctuations for the period 2002-2015. This may be due to the instability in oil prices.

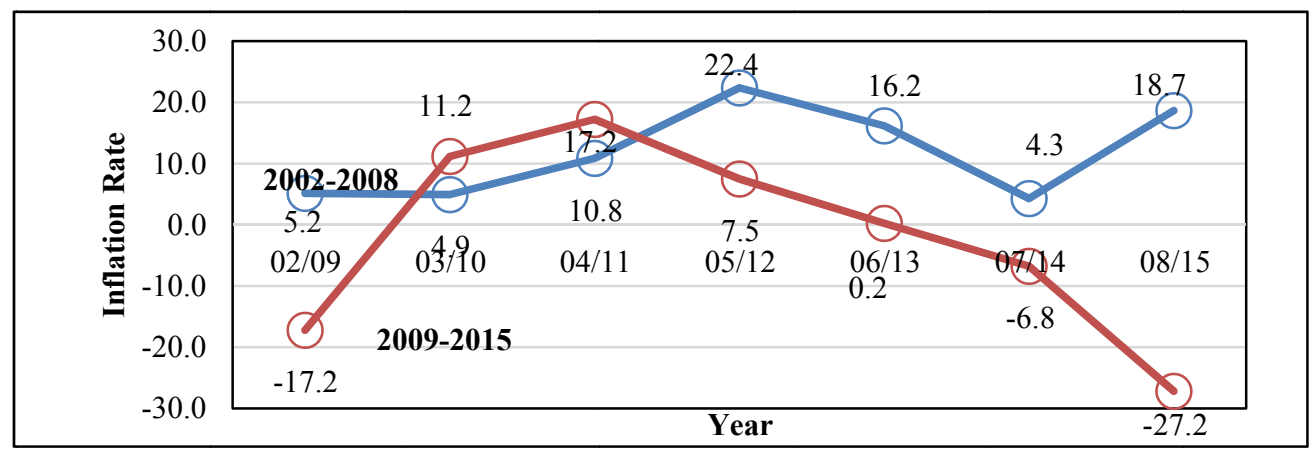

Figure 8. Inflation Rate, Kuwait, 2002-2015

The inflation rate is presented in the above Figure 8. Fluctuations are seen for the period 2002-2008 and negative values are observed for the period 2009 and 2015.

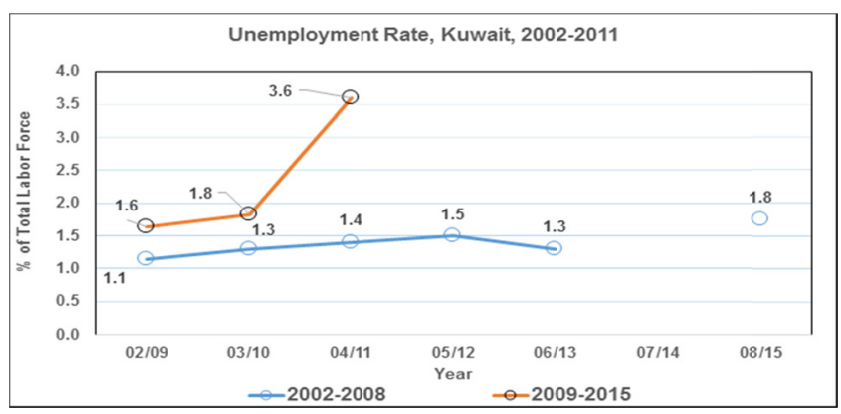

Figure 9. Unemployment Rate, Kuwait, 2002-2011 
From Figure 9, it is observed that Unemployment rate increased over the study period.

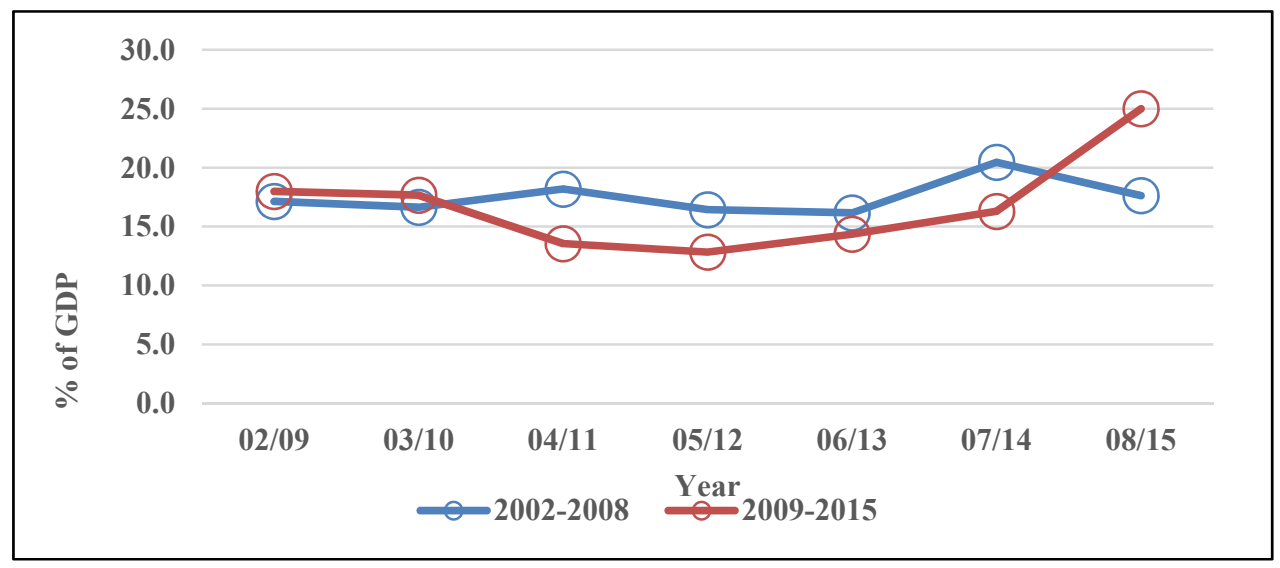

Figure 10. Gross Capital Formation as a \% of GDP, Kuwait, 2002-2015

The above Figure 10 shows that Gross capital formation as a \% of GDP is similar in both periods with slight variation.

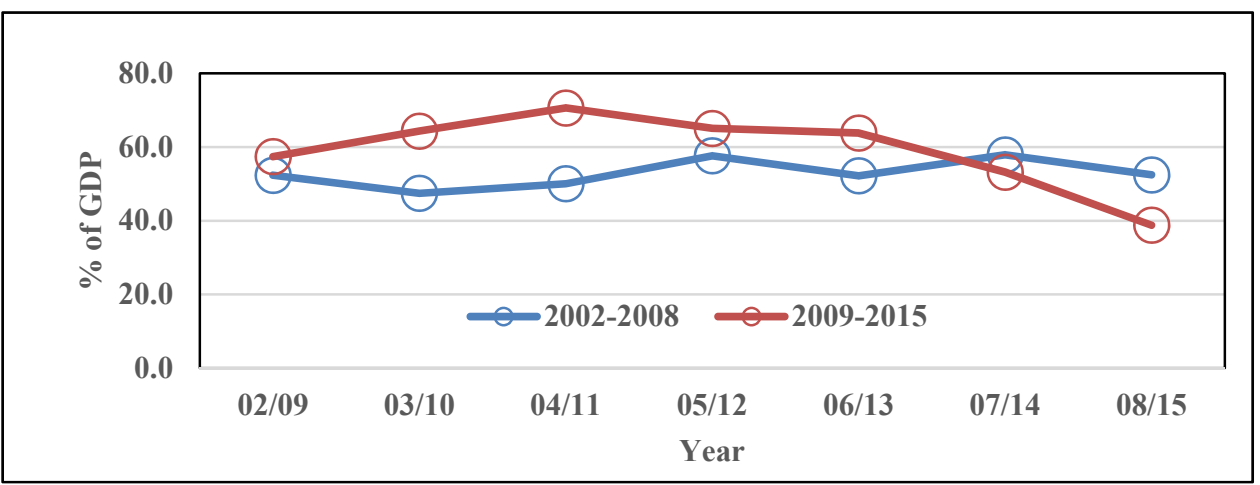

Figure 11. Revenue as a \% of GDP, Kuwait, 2002-2015

Figure 11 shows that Revenue as a percentage of GDP was higher initially for the period 2009-2013 and then took a plunge after that an was lower than for the period 2002-2008

All the above graphs reveal the performance of the various economic variables in the Kuwait economy.

\section{Performance of Trade in Kuwait Economy}

This section is discussed in two parts. In the first part the performance of exports and imports, and index of openness are presented and in the second part, the estimates for Reveled Comparative Advantage commodities and for specific years are given. The choice of the period and commodities is dictated by availability of data.

\subsection{Trade performance}

\section{Index of Openness}

The Index of Openness indicator is defined as follows (at current prices, current exchange rates):

Imports + exports (both goods and services)

GDP

Goods consist of merchandise imports and exports. Services cover transport, travel, communications, construction, IT, financial, other business, personal and government services, as well as royalties and license fees.

The trade to GDP ratio is the sum of exports and imports divided by GDP. This indicator measures the 'openness' or 'integration' in the world economy. It is the combined weight of total trade in its economy, and is a measure of the degree of dependence of domestic producers on foreign markets and their trade orientation (for exports) and the degree of reliance of domestic demand on foreign supply of goods and services (imports).

Trade (both imports and exports) is vital to any successful modern economy. It is crucial for the competitiveness of the Kuwait economy in the long run. It is said that by exposing firms and products to international competition, economies are encouraged to focus on areas of comparative advantage. This helps to ensure that scarce skills and resources are deployed where they are most productive. Further trade increases, among other things, competition, enables firms to capitalize on economies of scale by having access to larger markets and encourages the spread of skills, knowledge and innovation. The index of openness indicator will be influenced not only by the trade policies adopted by Kuwait and the result of multilateral trade negotiations but also, by the state of the world economy in the macro sense. 


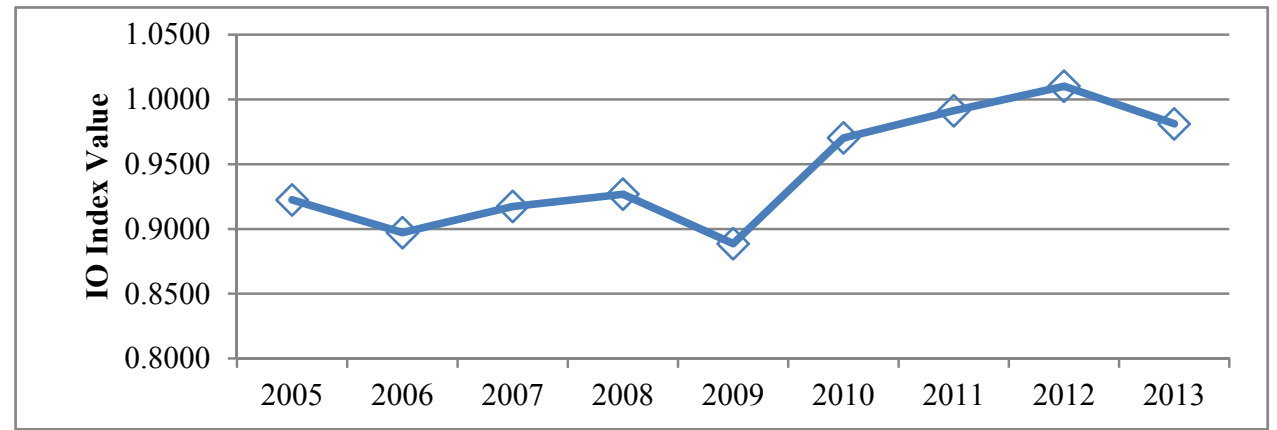

Figure 12. Kuwaiti Index of Openness, 2005 to 2013

From the Figure 12 it is observed that the index was at its peak in 2012. The year 2013 shows a decline. Increasing trend is observed from 2010-2012. The conclusion is that Kuwait is a very open economy.

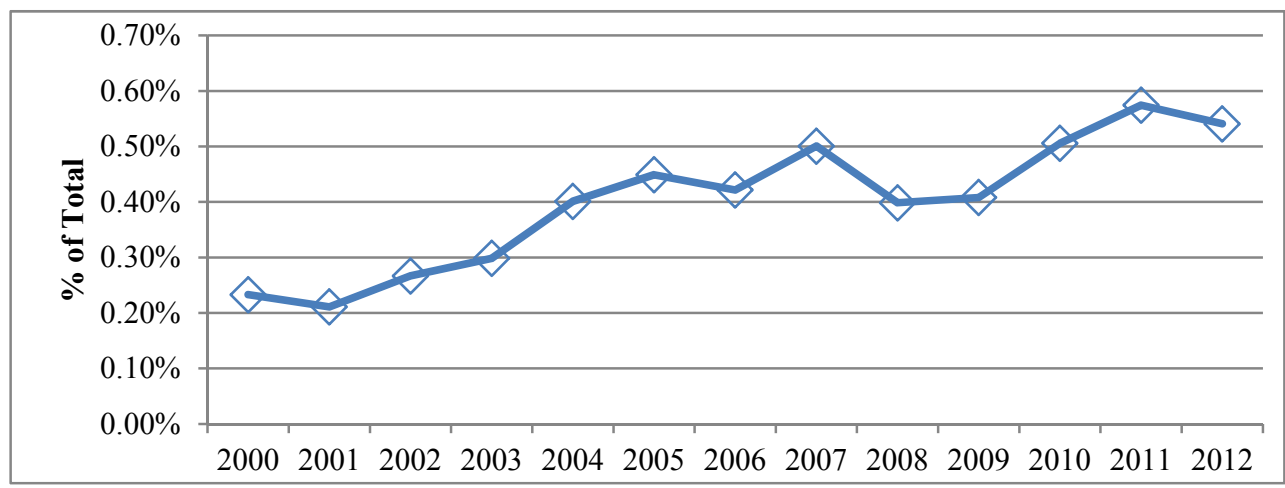

Figure 13. Total Kuwait Exports as a \% of World Exports

From Figure 13, although there are slight fluctuations in Total Kuwait exports as a \% of World exports the general trend is an increasing one.



Figure 14. Exports of Goods \& Services as a \% of GDP, Kuwait, 2002-2015

The above Figure 14 reveals that exports of goods and services as a \% of GDP are consistently higher increasing from 20022014 and then declined.

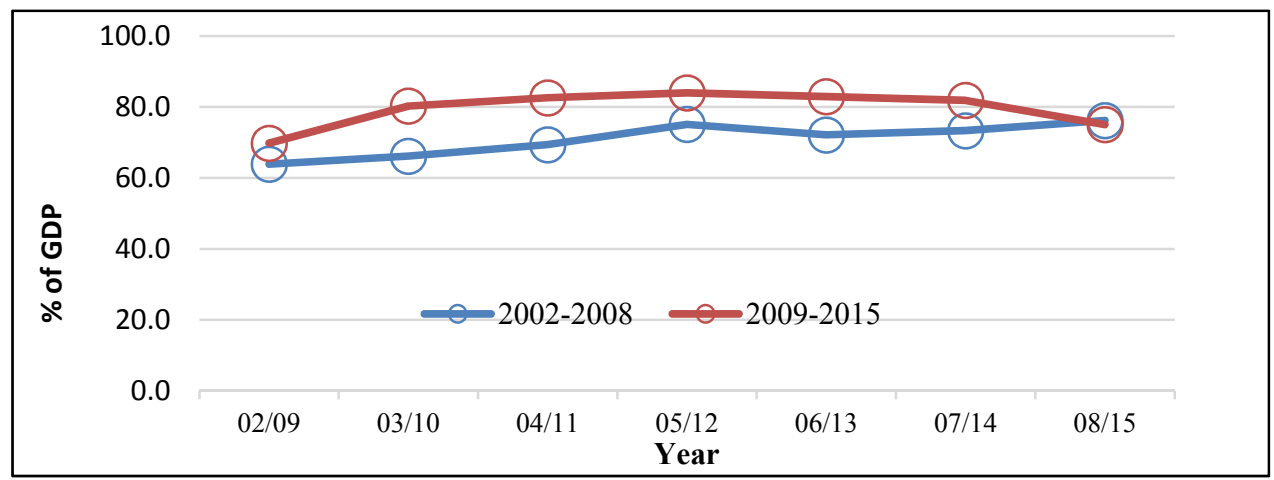

Figure 15. Merchandise Trade as a \% of GDP, Kuwait, 2002-2015 
Merchandise Trade as a \% of GDP is given in Figure 15 and this reveals that there is a consistent increase from 2002-2015 although a decline is observed in the last year 2015.

\section{Revealed Comparative Advantage}

The Revealed Comparative Advantage (RCA) is a trade analysis tool to measure and assess the competitive advantage of the product which the business people need to export. The RCA indicates whether a country's product is in the process of extending the products in which it has a trade potential or simply competitive advantage.

The Revealed Comparative Advantage (RCA) is defined as a country's sectoral share divided by the world sectoral share. The values of an RCA indicate the country's competitiveness vis-a-vis the world. It also helps to assess a country's export potential.

Revealed Comparative Advantage is used to capture the degree of trade specialization of a country. If the index is higher than one, it implies that its exports of those products are more than expected on the basis of its importance in total exports of the world.

$\mathrm{RCAij}=(\mathrm{Xij} / \mathrm{Xi}) /(\mathrm{Xaj} / \mathrm{Xa})$

RCA index of Revealed Comparative Advantage

$\mathrm{Xij}=$ exports of product $\mathrm{j}$ from country $\mathrm{i}$

$\mathrm{Xi}=$ total exports from country $\mathrm{i}$

$\mathrm{Xaj}=$ total exports of product $\mathrm{j}$ from the world

$\mathrm{Xa}=$ total exports of the world.

The numerator is the share of good $\mathrm{i}$ in the exports of country s, while the denominator is the share of good $\mathrm{i}$ in the exports of the world.

Possible Interpretations of RCA values:

- A value of less than unity implied that the country has a revealed comparative disadvantage in the product. However for a company to take a decision on the basis of the RCA values, a small value of RCA could also mean lesser domestic players from the country in question exporting that particular product and could mean an opportunity for the start-up SME firms.A RCA value is greater than 1 for a certain product signifies that the country has exported that commodity more intensively than the rest of the world in that year and generally this is taken as a proxy measure of a country's competitiveness. On the other word, it indicated that if the index exceeds unity, the country is said to have a revealed comparative advantage in the product.

- A fluctuating values of RCA across the years could mean a strict government policy interventions/control or else a fluctuating demand in the certain influential traditional markets for that product.

- A sudden rise in the RCA value could be due to possibility of innovation in terms of product or process or design etc. It could also be an indication of a recent announced export subsidy or incentive on that product giving a sudden flip to the product export.

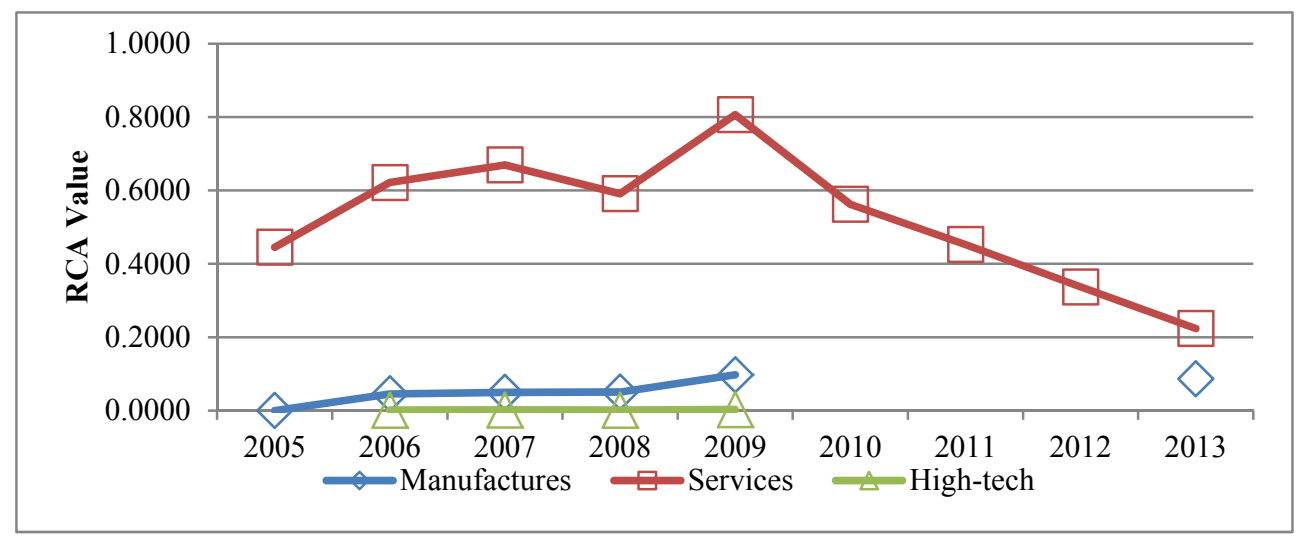

Figure 16. Revealed Comparative Advantage for Select Kuwaiti Exports

Figure 17. RCA Values for Select Kuwait Exports

\begin{tabular}{|c|c|c|c|}
\hline Year & Manufactures Exports & Services Exports & High-tech Exports \\
\hline 2000 & 0.0689 & & 0.0005 \\
\hline 2001 & 0.0802 & & 0.0006 \\
\hline 2002 & 0.0849 & & 0.0006 \\
\hline 2003 & 0.0648 & & 0.0003 \\
\hline 2004 & 0.0577 & & 0.0003 \\
\hline
\end{tabular}




$\begin{array}{llll}2005 & & 0.4452 & 0.0007 \\ 2006 & 0.0453 & 0.6217 & 0.0013 \\ 2007 & 0.0494 & 0.6695 & 0.0009 \\ 2008 & 0.0502 & 0.5911 & 0.0026 \\ 2009 & 0.0975 & 0.8064 & \\ 2010 & & 0.5622 & \\ 2011 & & 0.4526 & \\ 2012 & & 0.3371 & \\ 2013 & 0.0862 & 0.2238 & 0.2573 \\ 2014 & & \end{array}$

Source: UN Comtrade, Database, 2015.

Both Manufactures and High tech yielded low values for RCA whereas the Services depicted an increasing trend from 2005-2009 and then declined from 2009 to 2014.

\section{References}

Balassa, B. (1965). Trade Liberalization and 'Revealed' Comparative Advantage. Manchester School, 33, 99-123.

Balassa, B. (1967). Revealed Comparative Advantage Revisited: Analysis of Relative Export Shares of the Industrial Countries, 1953-1971. Manchester School, 45, 327-44.

Balassa, B., \& Marcus Noland (1989). Revealed Comparative Advantage in Japan and the United States. Journal of International Economic Integration, 2(2). https://doi:10.11130/jei.1989.4.2.8

Bypassed by Dubai, Kuwait fails to keep up with its neighbours (December 1, 2016). Middle East and Africa Kuwait City.

Central Intelligence Agency (CIA). $\quad$ World $\quad$ Fact $\quad$ Book, 2016. https://www.cia.gov/library/publications/resources/theworld-factbook/

Foster Wheeler USA Corporation. PESTLE Analysis of Kuwait 2013. (August 2013). Ref: 13-101689-02. KNPC Refineries Expansion/Upgrading Study.

http://databank.worldbank.org/data/home.aspx

http://www.theodora.com/wfbcurrent/kuwait/kuwait_economy.html

https://www.imf.org/.../Articles/.../MS111516-Kuwait-Staff-Concluding-Statement. (November 15, 2016)

Kuwait Economy, Politics and GDP Growth Summary - The Economist country.eiu.com/kuwait

https://www.imf.org/.../Articles/.../MS111516-Kuwait-Staff-Concluding-Statement. (November 15, 2016)

www.al-monitor.com/pulse/.../kuwait-economy-improvements-crunch-vitality.html (Nov 11, 2016)

www.worldbank.org/en/country/gcc/.../kuwaits-economic-outlook-fall-2016

\section{Appendices}

Figure 1 and 2. Population, Kuwait, 2002-2015

\begin{tabular}{lcc}
\hline Year & Population & Population density (people per sq. km of land area) \\
\hline $\mathbf{2 0 0 2}$ & $2,143,833$ & 120.3 \\
$\mathbf{2 0 0 3}$ & $2,169,118$ & 121.7 \\
$\mathbf{2 0 0 4}$ & $2,207,939$ & 123.9 \\
$\mathbf{2 0 0 5}$ & $2,276,623$ & 127.8 \\
$\mathbf{2 0 0 6}$ & $2,377,258$ & 133.4 \\
$\mathbf{2 0 0 7}$ & $2,503,410$ & 140.5 \\
$\mathbf{2 0 0 8}$ & $2,652,340$ & 148.8 \\
$\mathbf{2 0 0 9}$ & $2,818,939$ & 158.2 \\
$\mathbf{2 0 1 0}$ & $2,998,083$ & 168.2 \\
$\mathbf{2 0 1 1}$ & $3,191,051$ & 179.1 \\
$\mathbf{2 0 1 2}$ & $3,395,556$ & 190.5 \\
$\mathbf{2 0 1 3}$ & $3,598,385$ & 201.9 \\
$\mathbf{2 0 1 4}$ & $3,782,450$ & 212.3 \\
$\mathbf{2 0 1 5}$ & $3,935,794$ & 220.9 \\
\hline
\end{tabular}


Figure 3. \% Growth in Urban Population, Kuwait, 2002-2015

\begin{tabular}{lc}
\hline Year & \% Annual Growth \\
2002 & 1.6 \\
2003 & 1.2 \\
2004 & 1.8 \\
2005 & 3.1 \\
2006 & 4.3 \\
2007 & 5.2 \\
2008 & 5.8 \\
2009 & 6.1 \\
2010 & 6.2 \\
2011 & 6.2 \\
2012 & 6.2 \\
2013 & 5.8 \\
2014 & 5.0 \\
2015 & 4.0 \\
\hline
\end{tabular}

Figure 4,5,6 and 8. Gross Domestic Product-related Values, Kuwait, 2002-2015

\begin{tabular}{cccc}
\hline Year & GDP (Current US\%) 2002-2008 & GDP growth (annual \%) & Inflation, GDP deflator (annual \%) \\
\hline 2002 & $\$ 38,137,545,245$ & 3.0 & 5.2 \\
2003 & $47,875,838,926$ & 17.3 & 4.9 \\
2004 & $59,440,108,585$ & 10.8 & 10.8 \\
2005 & $80,797,945,205$ & 10.1 & 22.4 \\
2006 & $101,550,654,721$ & 7.5 & 16.2 \\
2007 & $114,641,097,818$ & 6.0 & 4.3 \\
2008 & $147,395,833,333$ & 2.5 & 18.7 \\
2009 & $105,899,930,507$ & -7.1 & -17.2 \\
2010 & $115,419,050,942$ & -2.4 & 11.2 \\
2011 & $154,027,536,232$ & 9.6 & 17.2 \\
2012 & $174,070,025,009$ & 6.6 & 7.5 \\
2013 & $174,161,495,063$ & 1.1 & 0.2 \\
2014 & $162,631,763,879$ & 0.5 & -6.8 \\
2015 & $114,041,209,704$ & 1.8 & -27.2 \\
\hline
\end{tabular}

Source: World Bank, Databank, 2017

Figure 9. Kuwait Unemployment Rate

\begin{tabular}{lc}
\hline Year & Unemployment Rate \\
\hline 2002 & 1.1 \\
2003 & 1.3 \\
2004 & 1.4 \\
2005 & 1.5 \\
2006 & 1.3 \\
2007 & NA \\
2008 & 1.8 \\
2009 & 1.6 \\
2010 & 1.8 \\
2011 & 3.6 \\
2012 & NA \\
2013 & NA \\
2014 & NA \\
2015 & NA \\
\hline
\end{tabular}


Gross National Income, Kuwait, 2002-2015

\begin{tabular}{|c|c|c|c|c|}
\hline & $\begin{array}{c}\text { GNI, Atlas method (current } \\
\text { US\$) }\end{array}$ & $\begin{array}{l}\text { GNI per capita, Atlas } \\
\text { method (current US\$) }\end{array}$ & $\begin{array}{l}\text { GNI, PPP (current } \\
\text { international \$) }\end{array}$ & $\begin{array}{c}\text { GNI per capita, PPP (current } \\
\text { international \$) }\end{array}$ \\
\hline 2002 & $\$ 40,499,264,957$ & $\$ 18,890$ & $\$ 133,126,442,714$ & $\$ 62,100$ \\
\hline 2003 & $48,845,783,299$ & 22,520 & $156,820,224,628$ & 72,300 \\
\hline 2004 & $62,035,746,832$ & 28,100 & $181,317,779,004$ & 82,120 \\
\hline 2005 & $78,321,130,397$ & 34,400 & $206,311,597,103$ & 90,620 \\
\hline 2006 & $98,291,913,826$ & 41,350 & $232,650,743,842$ & 97,870 \\
\hline 2007 & $119,141,104,847$ & 47,590 & $253,188,698,631$ & 101,140 \\
\hline 2008 & $137,351,808,666$ & 51,790 & $256,141,861,929$ & 96,570 \\
\hline 2009 & $129,674,446,849$ & 46,000 & $243,335,477,724$ & 86,320 \\
\hline 2010 & $126,114,335,697$ & 42,060 & $237,103,277,875$ & 79,080 \\
\hline 2011 & $138,843,572,852$ & 43,510 & $261,909,682,318$ & 82,080 \\
\hline 2012 & $169,624,637,549$ & 49,950 & $287,989,538,164$ & 84,810 \\
\hline 2013 & $187,083,429,406$ & 51,990 & $296,875,600,878$ & 82,500 \\
\hline 2014 & $187,315,487,092$ & 49,520 & $307,820,169,631$ & 81,380 \\
\hline 2015 & $164,040,880,973$ & 41,680 & $328,320,751,288$ & 83,420 \\
\hline
\end{tabular}

Figure 10 and 11 - Selected Kuwait Economic Characteristics - Investment \& Revenue

\begin{tabular}{|c|c|c|c|c|c|c|c|}
\hline Series Name & 2002 & 2003 & 2004 & 2005 & 2006 & 2007 & 2008 \\
\hline Gross capital formation ( $\%$ of GDP) & 17.1 & 16.6 & 18.2 & 16.4 & 16.2 & 20.5 & 17.6 \\
\hline Revenue, excluding grants ( $\%$ of GDP) & 52.4 & 47.5 & 50.1 & 57.6 & 52.2 & 57.9 & 52.5 \\
\hline Domestic credit provided by fin. sector ( $\%$ of GDP) & 81.8 & 76.7 & 65.1 & 55.3 & 59.9 & 69.8 & 66.2 \\
\hline Tax revenue ( $\%$ of GDP) & 1.2 & 1.3 & 1.3 & 1.0 & 1.0 & 1.1 & 0.9 \\
\hline Table 4B & 2009 & 2010 & 2011 & 2012 & 2013 & 2014 & 2015 \\
\hline Gross capital formation ( $\%$ of GDP) & 18.0 & 17.7 & 13.5 & 12.8 & 14.4 & 16.3 & 25.0 \\
\hline Revenue, excluding grants ( $\%$ of GDP) & 57.4 & 64.3 & 70.6 & 65.1 & 63.8 & 53.2 & 38.8 \\
\hline Domestic credit provided by fin. sector ( $\%$ of GDP) & 90.5 & 75.3 & 59.4 & 51.4 & 54.3 & 61.1 & 87.4 \\
\hline Tax revenue ( $\%$ of GDP) & 1.0 & 1.0 & 0.8 & 0.7 & 0.8 & 0.9 & 1.4 \\
\hline
\end{tabular}

Figure 12. Calculation of Index of Openness for Kuwait

\begin{tabular}{cccc}
\hline Series Name & 2010 & 2011 & 2012 \\
\hline GDP (Current US\$) & $\$ 115,416,397,090$ & $\$ 154,034,941,942$ & $\$ 174,044,698,001$ \\
Exports (Current US\$) & $76,952,173,361$ & $112,783,968,226$ & $130,069,220,216$ \\
Imports (Current US\$) & $35,034,086,271$ & $39,894,348,460$ & $45,739,097,955$ \\
IO $=$ Exports + Imports/ GDP & 0.9703 & 0.9912 & 1.0101 \\
\hline
\end{tabular}

Source: World Bank, Databank, 2017

Figure 13 and 14. Selected Kuwait Economic Characteristics - Exports \& FDI

\begin{tabular}{|c|c|c|c|c|c|c|c|}
\hline Series Name & 2002 & 2003 & 2004 & 2005 & 2006 & 2007 & 2008 \\
\hline Exports of goods and services (\% of GDP) & 44.6 & 52.1 & 56.9 & 64.0 & 65.5 & 63.4 & 66.8 \\
\hline Imports of goods and services ( $\%$ of GDP) & 36.6 & 34.5 & 32.4 & 28.3 & 24.2 & 28.3 & 25.9 \\
\hline High-technology exports ( $\%$ of mnfd exps) & 0.2 & 0.1 & 0.1 & -- & 0.3 & 0.5 & 0.3 \\
\hline Merchandise trade (\% of GDP) & 63.9 & 66.1 & 69.4 & 75.1 & 72.1 & 73.3 & 76.2 \\
\hline FDI, net inflows (BoP, 1,000 s of curr US\$) & 3,619 & $-67,111$ & 23,753 & 233,904 & 121,306 & 111,536 & $-5,952$ \\
\hline Table 3B/Year & 2009 & 2010 & 2011 & 2012 & 2013 & 2014 & 2015 \\
\hline Exports of goods and services (\% of GDP) & 59.5 & 66.7 & 73.2 & 74.7 & 70.9 & 68.5 & 54.4 \\
\hline Imports of goods and services ( $\%$ of GDP) & 29.4 & 30.4 & 25.9 & 26.3 & 26.7 & 31.5 & 45.3 \\
\hline High-technology exports (\% of mnfd exps) & 0.5 & 3.0 & 2.7 & -- & 1.4 & 0.1 & 2.7 \\
\hline Merchandise trade ( $\%$ of GDP) & 69.8 & 80.3 & 82.6 & 84.0 & 82.9 & 81.9 & 75.1 \\
\hline FDI, net inflows (BoP, 1000's of curr US\$) & $1,113,588$ & $1,304,068$ & $3,259,068$ & $2,870,589$ & $1,433,630$ & 485,807 & 284,648 \\
\hline
\end{tabular}

\section{Copyrights}

Copyright for this article is retained by the author(s), with first publication rights granted to the journal.

This is an open-access article distributed under the terms and conditions of the Creative Commons Attribution license (http://creativecommons.org/licenses/by/4.0/). 